\title{
Management of Undescended testis : Our experience
}

\author{
FARYAL MATIN, A.F. MASUD, ARIFUR RAHMAN
}

\begin{abstract}
Back Ground: In the past, it was believed that the undescended testis suffered no adverse changes until after puberty and surgical intervention was not necessary until 12 to 15 years of age. In the recent past, orchiopexy has been recommended in the second year of life, but now orchiopexy is recommended at 6 month of age. This is because the first sign of damage to the testes are identified at about 6 month of age. Treatment of undescended testes improves fertility and endocrine function, reduces the risk of torsion \& trauma, facilitates examination of testis and creates a normalappearing scrotum. The mainstay of therapy for the palpable undescended testes is surgical orchiopexy with creation of a subdartos pouch. When the testis is nonpalpable diagnostic laparoscopy is useful for management planning
\end{abstract}

Aim: The aim of this study was to ascertain the experience of management of undescended testis in this hospital.

Methods: The study was conducted at Institute of Child Health \& Shishu Sasthya Foundation Hospital. Case notes of 57 patients who had undergone surgical management for undescended testis between December 1999 and November 20007 were reviewed. The patients were separated into 2 groups: patients with palpable undescended testis and patients with impalpable testis. Surgical management was not done before 6 month of age. Open orchiopexy was performed in palpable group. For impalpable group, diagnostic laparoscopy was done and managed accordingly.

Results: The median age at operation was 7.2 years (range 06 month to 14 years). Orchiopexy was done at the age of 6 month in 2 patients. Among 57 cases, thirty-six patients had palpable testes and twenty-one patients had impalpable testis. Twenty patients had right sided undescended testis and four had bilateral.

Clinical inguinal hernia was present in 2 cases with right sided palpable undescended testis.

Hypospadias was present in 1 patient with right sided palpable undescended testis. Open orchiopexy was performed in 36 patients (palpable group). Laparoscopy was done 21 patients (impalpable group).

In impalpable group (21) ultra-sonogram found testis in 7 cases and was doubtful in 2 cases. On diagnostic laparoscopy only 2 vanishing testes were found. Lap assisted single stage orchiopexy was performed in 1 patients. First stage of Fowler-Stephen was done laparoscopically in 18 cases. Second stage of this procedure was done in open method in 2 patients. There was no postoperative complication.

Conclusions: Orchiopexy is a safe procedure for the children even at the age of 6 months. With laparoscopy impalpable testis can be safely diagnosed and managed.

Introduction:

The importance of a descended testis has been known since ancient times, but the mechanism of descent remained obscure until 1786 when Hunter dissected the human fetus and found the intra-abdominal testis connected to the inguino-abdominal wall by a ligament called gubernaculum testis because it appeared to guide the testis to the scrotum ${ }^{1}$. Numerous factors interact to effect normal testicular descent. Any abnormality in this process can result in an

1. Assistant Professor, Surgery Department, Institute of Child Health \& Shishu Sasthya Foundation Hospital.

2. Professor \& head of the department, Surgery Department, Institute of Child Health \& Shishu Sasthya Foundation Hospital.

4. Associate Professor, Surgery Department, Institute of Child Health \& Shishu Sasthya Foundation Hospital. 
undescended testis, which carries fertility and malignancy implications.

Testicular development and descent depend on a complex interaction among endocrine, paracrine, growth and mechanical factors.

Undescended testis is defined as a testis that can not be manipulated to the bottom of the scrotum without undue tension on the spermatic cord. There is variability in nomenclature relating to undescended testis but the clearest classification is palpable and nonpalpable testis ${ }^{2}$.

Controversy persists about whether the testis is primarily abnormal, leading to maldescendent, or alternatively is undescended, leading to a secondary abnormality. Evidence now suggests that abnormalities seen postnatally in undescended testes are secondary ${ }^{3}$.

Scrotal testis resides in a specialized low-temperature environment with the pampiniform plexus, scrotal pigmentation, absence of subcutaneous fat. Low temperature is regulated by temperature-sensitive muscles- cremaster and dartos. All these ensure decreased temperature of the gonad. The scrotal testis in the human is maintained at $33^{\circ} \mathrm{C}$ compared with $34^{\circ} \mathrm{C}$ to $35^{\circ} \mathrm{C}$ noted in the inguinal region and $37^{\circ} \mathrm{C}$ intra-abdominally ${ }^{4}$. The physiology of the testis is well adapted to this lower temperature; therefore, in the undescended testis where the ambient temperature is increased the testis undergoes progressive alteration ${ }^{5}$.

Germ cell deficiency in cryptorchidism was previously regarded as congenital ${ }^{6}$. It has been observed that the histology of the testis is initially normal and becomes progressively abnormal with age. Mengle and associates first showed in a histologic study of 752 testicular biopsy specimens in children between 2 months and 15 years of age that the number of spermatogonia per tubule decreased by 3 years of age $^{7}$. Using electron microscopy, Handziselimovic and colleagues identified histologic abnormalities in the Leydig cells in the second year of life ${ }^{8}$. More detailed studies showed impaired Leydig cells development in undescended testes in the first 2 to 6 months, whereas the Sartoli and germ cells appeared normal ${ }^{9}$. By the end of the second year of life, nearly $40 \%$ of undescended testes had completely lost their germ cells. They concluded that germ cell deficiency in undescended testis is secondary ${ }^{9}$.
In previous generations, it was believed that the undescended testis suffered no adverse changes until after puberty and surgical intervention was not necessary until 12 to 15 years of age ${ }^{10}$. The evidence that germ cell maturation is already abnormal after 6 months of age has led clinicians to appreciate that not only is postnatal degeneration is important issue but also that early intervention may prevent it.

Paternity rates are not deficient in unilateral cryptorchidism; but with bilateral cryptorchidism, fertility is significantly impaired ${ }^{11}$. Data attempting to correlate fertility rates with timing of surgery are not yet available because there are no long-term studies of children undergoing orchiopexy in the first year of life.

The risk of developing testicular cancer is 5 to 60 times greater for men with cryptorchidism ${ }^{12}$. The increased risk may be due to an underlying genetic and hormonal etiology that causes both cryptorchidism and testicular cancer ${ }^{12}$. The association of orchiopexy with decrease in cancer risk has not been demonstrated prospectively ${ }^{13}$. Nevertheless, orchiopexy facilitates testicular examination and cancer detection.

Treatment of undescended testes improves fertility and endocrine function, reduces the risk of torsion \& trauma, facilitates examination of testis and creates a normal-appearing scrotum.

The undescended testis is unlikely to descend after age of 9 to 12 month of age. For some years, orchiopexy has been recommended in the second year of life, but now orchiopexy is recommended at 6 months of age. This is because the first sign of damage to the testes are identified at about 6 month of age ${ }^{14}$. Children present with concomitant inguinal hernia should have immediate herniotomy with orchiopexy.

The mainstay of therapy for the palpable undescended testes is surgical orchiopexy with creation of a subdartos pouch. The success rate, defined as a testis that remains in the scrotum and does not atrophy, is $95 \%{ }^{15}$. When the testis is nonpalpable diagnostic laparoscopy is useful for management planning ${ }^{16}$. If the testicular vessels are seen exiting the inguinal ring, an inguinal incision is used to locate testis or testicular remnant. Orchiopexy is performed if a viable testis is found. If the vessels end blindly in the inguinal canal (vanishing testis), the tip of vessels may be sent for pathologic examination. Remnants of 
testicular tissue or hemosiderin and calcifications are indicative of resorption of the testis ${ }^{17}$ and are likely the result of torsion of spermatic cord during migration. If the vessels are not seen exiting the inguinal ring and laparoscopy reveals an intra-abdominal testis, several options are available. The Fowler-Stephens orchiopexy involves ligation of spermatic vessels, which makes the testis, depend on the vasal and cremasteric arteries for viability ${ }^{18}$. For this reason, the Fowler-Stephens approach is not a good option after inguinal exploration because the blood supply of the testis may have been compromised. After ligation of testicular vessels, a delay of about 6 month is recommended before orchiopexy to allow collateral circulation development. The success rate of this procedure is greater than $80 \%{ }^{19}$. Other options for surgical management of intra-abdominal testis include micro vascular orchiopexy (auto transplant) ${ }^{20}$ or orchiotomy.

The aim of this study was to ascertain the experience of management of undescended testis in this hospital.

\section{Material and methods:}

The hospital records of 57 consecutive patients, all of whom underwent surgical management for undescended testis between December 1999 and November 20007 in Institute of Child Health \& Shishu Sasthya Foundation Hospital, were reviewed. The diagnosis was made by clinical examination, ultra sonogram and laparoscopy. The data collected from hospital records included the age at the time of operation, type of undescended testis and way of management. The patients were separated into 2 groups: patients with palpable undescended testis and patients with impalpable testis.

Preoperatively all the patients were investigated with ultra sonogram to detect site of testis (in impalpable group) and any associated anomaly. Laparoscopy was done in all impalpable group for diagnostic as well as therapeutic purpose if needed.

Surgical management was not done before 6 month of age. Open orchiopexy was performed in palpable group.

For impalpable group, diagnostic laparoscopy was done through an umbilical port. If it revealed intraabdominal healthy testis, an immediate orchiopexy was done if the testis could be pulled to the opposite internal inguinal ring.
If the testis could not be pulled to the opposite internal inguinal ring, first stage of Fowler-Stephen was performed by coagulating testicular vessels laparoscopically. After 6 month, the condition of testis was examined with laparoscopy. If the testis was viable then the testis was mobilized on a flap of peritoneum in open method.

If the testis was not present and vessels end blindly, then procedure was closed.

All patients were discharged on $2^{\text {nd }}$ POD. The condition of testis was followed up for at least two weeks.

\section{Results:}

The median age at operation was 7.2 years (range 06 month to 14 years). Orchiopexy was done at the age of 6 month in 2 patients.

Among 57 cases, thirty-six patients had palpable testes and twenty-one patients had impalpable testis.

Twenty patients had right sided undescended testis and four had bilateral.

Clinical inguinal hernia was present in 2 cases with right sided palpable undescended testis.

Hypospadias was present in 1 patient with right sided palpable undescended testis.

Open orchiopexy was performed in 36 patients (palpable group). Laparoscopy was done 21 patients (impalpable group).

In impalpable group (21) ultra-sonogram found testis in 7 cases and was doubtful in 2 cases. On diagnostic laparoscopy only 2 vanishing testes were found. Lap assisted single stage orchiopexy was performed in 1 patients. First stage of Fowler-Stephen was done laparoscopically in 18 cases. Second stage of this procedure was done in open method in 2 patients.

Table-I

Results of undescended testes

Group- I Palpable- 36 (63\%)

Group- II Impalpable- Vanishing testes-2

$21(36 \%) \quad$ Single stage orchiopexy- 1

First stage of staged

orchiopexy- 18

There was no postoperative complication. 


\section{Discussion:}

Undescended testis occurs in 3\% of term infant boys and in up to $33 \%$ of premature boys. The majority of testes descend within the first 9 to 12 months. At age 1 year, the incidence of undescended testis is $1 \%$ 21. In this study the mean age of patients was 7.2 years.

Series documenting the location of undescended testis find that two third to three fourth of cases are palpable 22. In our study about two third cases were palpable.

Anomalies associated with undescended testis include patent processus vaginalis, inguinal hernia, hypospadias, posterior urethral valve and anomalies of the upper urinary tract ${ }^{23}$. This study finds inguinal hernia in 2 cases with right sided palpable undescended testis. Hypospadias was present in 1 patient with right sided palpable undescended testis.

For impalpable undescended testis numerous imaging techniques have been recommended to identify the position of testis ${ }^{24}$. These include ultrasonography, computed tomography, magnetic resonance imaging and spermatic venography and angiography. Recently laparoscopy has become the most common way to identify the position of intra-abdominal testis and to exclude vanishing testis ${ }^{25}$. In our study

ultra-sonogram found testis in 7 cases and was doubtful in 2 cases in impalpable group (21). On diagnostic laparoscopy only 2 vanishing testes were found.

The success rate of open orchiopexy for palpable testis is $95 \%$. In this study there was no reduction of testicular size on palpation post- operatively.

In follow-up studies of two-stage Fowler-Stephens procedure for abdominal testis researchers' report $70 \%$ to $90 \%$ scrotal position without atrophy ${ }^{26}$. In our study two stages of Fowler-Stephens procedure was completed in 2 patients. On manual examination, the testicular size was not reduced in post-operative followup.

In the hands of experienced surgeons the risk of complication after orchiopexy should be less than 5\% 27. The most common complication after orchiopexy is wound infection. Secondary atrophy of the testis is uncommon. Hemorrhage in the wound secondary to poor hemostasis occurs occasionally. However, in our study there was no post orchiopexy complication.
The risk of atrophy after orchiopexy increased if simultaneous incarcerated hernia present, if a second operation is needed to bring the testis to the scrotum. The age at operation is not a risk factor for postoperative complication if skill surgeon has done the procedure. Stoey and colleagues compared 100 infants younger than 2 years of age with 100 toddlers or older children undergoing orchiopexy after age of 2 years. They found an incidence of testicular atrophy of $5 \%$ in both groups, suggesting that the risk of postoperative atrophy is not directly related to age in pediatric surgical centers ${ }^{28}$.

In conclusion it can be said from this study that orchiopexy is a safe procedure for the children even at the age of 6 months. Surgery at this age may prevent postnatal degeneration. With laparoscopy impalpable testis can be safely diagnosed and managed.

\section{References:}

1. Hunter J: Adescription of the situation of the testis in the fetus, with its descend in to the scrotum. In Observstions on Certain Parts of the Animal Oeconomy. London, Castle-Street Leicester Square, 1786.

2. Kaplan G: Nomenclature of cryptorchidism. Eur J Pediatr 152: 17, 1993

3. de Krester DM, Risbridger GP: Changes in Sertoli cell structure and function. In Hutson JM, Beasley SW (eds): The Cryptorchid Testis. Boca Raton, FL, CRC Press, 1989.

4. Mieusset R, Fouda PJ, Vaysse P, et al: Increase in testicular temperature in case of cryptorchidism in boys. Fertil Steril 59: 1319, 1993.

5. Job JC, Toublanc JE, Chaussain JL, et al: Endocrine and immunological findings in cryptorchid infants. Horm Res 30: 167, 1988.

6. Scorer CG: Congenital Deformities of the Testis and Epididymis. London, Butterworths, 1971.

7. Mengel W, Hienz HA, Sippe WG 2nd, Hecker WC:Studies on cryptorchidism: A comparison of histological findings in the germinative epithelium before and after the second year of life. J Peditr Surg 9:445, 1974.

8. Hadziselimovic F, Herzog B, Seguchi H: Surgical correction of cyptochidism at 2 years: Electron microscopic and morphometric investigations. J Pediatr Surg 10:19, 1975. 
9. Hadziselimovic F, Herzg B, Girard J, et al: Cryptorchidism- histology, fertility and treatment. Prog Reprod Bio Med 10:1, 1984.

10. Pike MC, Chilvers C, Peckham MJ: Effect of age at orchidopexy on risk of testicular cancer. Lancet 1:1264, 1986.

11. Lee PA, Coughlin MT, Bellinger MF: Paternity and hormone levels after unilateral cryptorchidism: Association with pretreatment testicular location. J Urol 164:1697, 2000.

12. Herrinton LJ, Zhao W, Husson G: Management of cryptorchism and risk of testicular cancer. Am J Epidemiol 157::602, 2003.

13. Giwereman A, Muller J, Shakkebaek NE: Cryptorchidism and testicular neoplasia. Horm Res 30:157, 1988.

14. Huff DS, Hadziselimovic F, Snyder HM 3rd, et al: Early postnatal testicular malcevelopment in cryptorchidism. J Urol 146:624, 1991.

15. Saw KC, Eardley I, Dennis MJ, et al: Surgical outcome of orchiopexy, I: Previously unoperated testes. Br J Urol 70:90, 1992.

16. Merguerian PA, Mevorach RA, Shortliffe LD, et al: Laparoscopy for the evaluation and management of the nonpalpable testicle. Urology 51(5A):3, 1998.

17. Diamond DA, Caldamone AA, Elder JS: Prevalence of the vanishing testis in boys with a unilateral impalpable testis: Is the siode of presentation significant? J Urol 152:502, 1994.

18. Stanford LG, Perez LM, Joseph DB: Two-stage Fowler-Stephens orchiopexy with laparoscopic clipping of spermatic vessels. J Urol 158: 1205, 1997.
19. Lindgren BW, Franco I, Blick S, et al: Laparoscopic Fowler-Stephens orchiopexy for the high abdominal testis. J Urol 162:990, 1999.

20. Frey $P$, Bianchi $A$ : Microvascular autotransplantation of intra-abdominal testes. Progr Pediatr Surg 23:115, 1989.

21. Pohl HG, Belman AB: The location and fate of the cryptorchid and impalpable testes. In Peppas DS, Erlich RM (eds): Dialogues in Pediatric Urology, vol 20:1. Pearl River, NY, William J, Miller Associates, pp 3-4, 1997.

22. Docimo SG: The results of surgical therapy for cryptorchidism: A literature review and analysis. J Urol 154:1148, 1995.

23. Rozanski TA, Bloom DA: The undescended testis. Theory and management. Urol Clin North Am 22: 107, 1995.

24. Hrebinko RL, Bellinger MF: The limited role of imaging techniques in managing children with undescended testes. J Urol 150:458, 1993.

25. Moor RG, Peters CA, Bauer SB, et al: Laparoscopic evaluation of the nonpalpable testis: A prospective assessment of accuracy. J Urol 151:728, 1994.

26. Elder JS: Two-stage Fowler-Stephens orchiopexy in the management intras-abdominal testes. J Urol 148:1239, 1992.

27. Hutson JM, Woodward AA,Beasley SW: Jones' Clinical Paediatric Surgery: Diagnosis and management, 5th ed. Melbourne, Blackwell Scientific, 1999.

28. Wilson-Storey D, McGenity K, Dickson JAS: Orchidopexy: The younger the better? J R Coll Surg (Edinb) 35:362, 1990. 